\title{
PENERAPAN METODE PEMBELAJARAN ROLE PLAYING UNTUK MENINGKATKAN AKTIVITAS BELAJAR SISWA PADA MATA PELAJARAN IPS DI KELAS III SDN 056612 PASAR BATU
}

\author{
Irmalati \\ Guru SD Negeri No. 056612 Pasar Batu \\ Surel : irmalatis@yahoo.com
}

\begin{abstract}
The Application Of Learning Methods Role Playing To Enhance The Student Learning Activities Lesson IPS In Class III SD Negeri No. 056612 Pasar Batu 2015/2016. This research aims to improve students' learning activities using Learning Methods Role Playing in class III SD Negeri No. 056612 Pasar Batu. These research subjects are 21 students. The study lasted for two cycles can be concluded that 1) Activities of student learning through the implementation of the Learning Methods Role Playing is based on observations of the two observers increased from the first cycle to the second cycle. 2) The results of student learning through the implementation of the Learning Methods Role Playing increases from the first cycle to the second cycle.
\end{abstract}

Keywords: Learning Methods Role Playing, Student Activities

\begin{abstract}
Abstrak : Penerapan Metode Pembelajaran Role Playing Untuk Meningkatkan Aktivitas Belajar Siswa Pada Mata Pelajaran IPS Di Kelas III SD Negeri No. 056612 Pasar Batu T.A 2015/2016. Penelitian ini bertujuan untuk meningkatkan aktivitas belajar siswa dengan menggunakan metode pembelajaran Role Playing di kelas III SD Negeri No. 056612 Pasar Batu. Subjek penelitian ini berjumlah 21 orang siswa. Penelitian berlangsung selama dua siklus dapat disimpulkan bahwa 1) Aktivitas belajar siswa melalui penerapan metode pembelajaran Role Playing berdasarkan pengamatan kedua pengamat mengalami peningkatan dari siklus I ke siklus II. 2) Hasil belajar siswa melalui penerapan metode pembelajaran Role Playing meningkat dari siklus I ke siklus II.
\end{abstract}

Kata Kunci: Metode pembelajaran Role Playing, Aktivitas Siswa

\section{PENDAHULUAN}

Proses pembelajaran yang berlangsung di SD Negeri No. 056612 Pasar Batu selama ini masih menerapkan metode ceramah. Peneliti menganggap bahwa penerapan metode ceramah ini dapat memberikan informasi kepada siswa secara langsung sehingga diharapkan siswa memahami materi yang disampaikan oleh peneliti.

Namun pada kenyataannya pada semester genap ini siswa kelas III SD Negeri No. 056612 Pasar Batu, hanya 8 dari 21 siswa yang memperoleh nilai di atas KKM pada mata pelajaran IPS. Hal ini menunjukkan siswa tidak memahami materi yang selama ini peneliti sampaikan. Karena itu peneliti melakukan analisis untuk menemukan masalah apa saja yang menjadi faktor rendahnya hasil belajar siswa di kelas III SD Negeri No. 056612 Pasar Batu. Masalah-masalah tersebut antara lain, rendahnya tingkat penguasaan peserta didik terhadap materi pembelajaran IPS. Peserta didik kurang aktif dalam proses pembelajaran karena metode pembelajaran yang digunakan kurang efektif dan tidak mendukung aktivitas siswa. Kemampuan peserta didik dalam mengaitkan pembelajaran dengan kehidupan sehari-hari masih rendah. Peneliti dominan menerangkan dengan berceramah pada saat pembelajaran dan pembelajaran IPS masih bersifat 
monoton, kurang menarik, dan terpusat pada buku (teks book).

Upaya yang peneliti lakukan untuk meningkatkn hasil belajar siswa adalah melakukan penelitian tindakan kelas dengan menerapkan metode pembelajaran Role Playing. Metode pembelajaran ini dipilih karena metode ini diharapkan dapat melatih siswa menjadi aktif dan dapat memberikan variasi baru bagi siswa selama belajar bahasa indonesia agar siswa tidak merasa bosan.

Metode pembelajaran dengan Role Playing adalah suatu cara penguasaan bahan-bahan pelajaran melalui pengembangan imajinasi dan penghayatan siswa. Pengembangan imajinasi dan penghayatan itu dilakukan siswa dengan memerankannya sebagai tokoh hidup atau benda mati. Metode ini banyak melibatkan siswa dan membuat siswa senang belajar serta metode ini mempunyai nilai tambah, yaitu: a) dapat menjamin poartisipasi seluruh siswa dan memberi kesempatan yang sama untuk menunjukkan kemampuannya dalam bekerjasama hingga berhasil, dan b) permainan merupakan pengalaman yang menyenangkan bagi siswa. Pembelajaran dengan Role Playing merupakan suatu aktivitas yang dramatik, biasanya ditampilkan oleh sekelompok kecil siswa, bertujuan mengeksploitasi beberapa masalah yang ditemukan untuk melengkapi partisipasi dan pengamat dengan pengalaman belajar yang nantinya dapat meningkatkan pemahaman. Sehingga penerapan metode pembelajaran ini diharapkan dapat meningkatkan aktivitas dan hasil belajar siswa.

Berdasarkan latar belakang di atas, maka dapat dirumuskan suatu masalah sebagai berikut; 1) Apakah metode pembelajaran Role Playing dapat meningkatkan aktivitas belajar siswa pada mata pelajaran IPS di Kelas III SD Negeri No. 056612 Pasar Batu T.A 2015/2016?; 2) Apakah metode pembelajaran Role Playing dapat meningkatkan hasil belajar siswa pada mata pelajaran IPS di Kelas III SD Negeri No. 056612 Pasar Batu T.A 2015/2016?

Sesuai dengan permasalahan di atas, penelitian ini bertujuan untuk; 1) Untuk mengetahui apakah metode pembelajaran Role Playing dapat meningkatkan aktivitas belajar siswa pada mata pelajaran IPS di Kelas III SD Negeri No. 056612 Pasar Batu T.A 2015/2016; 2). Untuk mengetahui apakah metode pembelajaran Role Playing dapat meningkatkan hasil belajar siswa pada mata pelajaran IPS di Kelas III SD Negeri No. 056612 Pasar Batu T.A 2015/2016.

Dalam suatu proses belajar mengajar ada beberapa komponen yang selalu terkait dan tidak bisa dipisahkan, yaitu media pengajaran, prosedur didaktif (metode), materi pelajaran dan lain-lain. "Semua komponen tersebut harus terpadu dan serasi agar tercipta suasana belajar mengajar yang menyenangkan, akhirnya terwujud suatu hal apa yang dinamakan dengan hasil belajar yang berbobot dan berkualitas (Winkel, 1991: 177).

Supaya pembelajaran IPS sesuai dengan tujuan yang diharapkan berupa pemahaman yang mendalam dan berantai dari siswa, diperlukan suatu pendekatan. Guru berperan penting dalam hal ini, dengan sadar berusaha mengatur lingkungan belajar agar bergairah bagi anak didik. Dengan seperangkat teori dan bekal pengalaman yang dimiliki, sebaiknya seorang guru haruslah mempersiapkan segala sesuatu sebelum melakukan pembelajaran, 
mempersiapkan program pengajaran dengan baik dan sistematis.

Salah satu usaha yang tidak pernah guru tinggalkan adalah bagaimana memahami kedudukan prosedur didaktif sebagai salah satu komponen yang ikut ambil bagian dalam keberhasilan kegiatan belajar mengajar. Dalam penggunaan metode atau prosedur didaktif terkadang seorang guru harus menyesuaikan dengan kondisi dan suasana kelas. Jumlah anak didik mempengaruhi penggunaan metode. Bervariasinya metode juga dapat menyulitkan guru. Sebagai cara untuk tercapainya tujuan intruksional dari pembelajaran matematika maka perlu adanya pemilihan penggunaan metode yang terbaik agar siswa merasa tertarik untuk mempelajari mata pelajaran matematika sebagaimana mestinya.

Pembelajaran dengan Role Playing adalah suatu cara penguasaan bahan-bahan pelajaran melalui pengembangan imajinasi dan penghayatan siswa. Pengembangan imajinasi dan penghayatan itu dilakukan siswa dengan memerankannya sebagai tokoh hidup atau benda mati. Metode ini banyak melibatkan siswa dan membuat siswa senang belajar serta metode ini mempunyai nilai tambah, yaitu: a) dapat menjamin poartisipasi seluruh siswa dan memberi kesempatan yang sama untuk menunjukkan kemampuannya dalam bekerjasama hingga berhasil, dan b) permainan merupakan pengalaman yang menyenangkan bagi siswa.

\section{METODE}

Penelitian ini dilakukan di SD Negeri No. 056612 Pasar Batu yang terletak di Jalan Pasar Batu Stabat Lama dan pelaksanaannya pada bulan Februari 2016 sampai dengan Juni 2016
Subjek dalam penelitian ini adalah peserta didik kelas III SD Negeri No. 056612 Pasar Batu. Pemilihan kelas III dikarenakan peneliti merupakan guru IPS kelas III SD Negeri No. 056612 Pasar Batu. Banyak subjek penelitian yakni 21 orang peserta didik.

Alat pengumpul data dalam penelitian ini adalah; 1) tes hasil belajar; 2) lembar observasi aktivitas siswa;

Penelitian ini menggunakan Penelitian Tindakan Kelas (PTK). PTK adalah suatu bentuk kajian yang bersifat reflektif oleh pelaku tindakan yang dilakukan untuk meningkatkan kemantapan rasional dari tindakan mereka dalam melaksanakan tugas, memperdalam pemahaman terhadap tindakan-tindakan yang dilakukan itu, serta memperbaiki kondisi dimana praktek pembelajaran tersebut dilakukan (dalam Mukhlis, 2000: 3).

Sesuai dengan jenis penelitian yang dipilih, yaitu penelitian tindakan kelas, maka penelitian ini menggunakan model penelitian tindakan dari Kemmis dan Taggart (dalam Sugiarti, 1997:6), yaitu berbentuk spiral dari sklus yang satu ke siklus yang berikutnya. Setiap siklus meliputi planning (rencana), action (tindakan), observation (pengamatan), dan reflection (refleksi). Langkah pada siklus berikutnya adalah perencanaan yang sudah direvisi, tindakan, pengamatan, dan refleksi. Sebelum masuk pada siklus I dilakukan tindakan pendahuluan yang berupa identifikasi permasalahan.

Metode Analisis Data pada penelitian ini digunakan metode deskriptif dengan membandingkan hasil belajar siswa sebelum tindakan dengan hasil belajar siswa setelah tindakan.

Langkah-langkah pengolahan data sebagai berikut: 
1. Merekapitulasi nilai pretes sebelum tindakan dan nilai tes akhir Siklus I dan Siklus II

2. Menghitung nilai rerata atau persentase hasil belajar siswa sebelum dilakukan tindakan dengan hasil belajar setelah dilakukan tindakan pada Siklus I dan Siklus II untuk mengetahui adanya peningkatan hasil belajar.

Sebagai tolak ukur keberhasilan penelitian tindakan kelas ini dapat dilihat hasil belajar yang dikonfirmasi dengan kriteria ketuntasan minimal (KKM) IPS untuk kelas III SD Negeri No. 056612 Pasar Batu sebesar 65, jika hasil belajar siswa mencapai KKM secara individual dan $\geq 85 \%$ jumlah siswa memperoleh nilai $\geq \mathrm{KKM}$ maka pembelajaran tuntas secara klasikal.

\section{PEMBAHASAN}

Penelitian tindakan kelas dilakukan dikelas III SD Negeri No. 056612 Pasar Batu dalam 2 Siklus dengan 4 kali pertemuan. Setiap Siklus terdiri dari beberapa langkah yaitu perencanaan, pelaksanaan, obsevasi, dan refleksi. Hasil penelitian didapat dari tes hasil belajar yang digunakan untuk melihat kemapuan siswa dan hasil pengamatan dengan menggunakan lembar observasi aktivitas siswa untuk melihat aktivitas siswa selama mengikuti pembelajaran dengen menerapkan metode pembelajaran Role Playing.

Kegiatan untuk mengetahui kondisi awal siswa dilakukan dengan tes kemampuan awal sebelum penerapan metode pembelajaran Role Playing. Tes kemampuan awal (tes kognitif) bertujuan untuk mengetahui seberapa besar kemampuan awal yang dimiliki siswa dalam memahami materi pada mata pelajaran IPS. Hasil tes kemampuan awal menunjukan rendahnya penguasan materi siswa kelas III SD Negeri No. 056612 Pasar Batu. Nilai rata-rata yang diperoleh siswa sebesar 50,95 dengan tak seorang pun siswa memperoleh nilai diatas KKM

Observasi menghasilkan data aktivitas belajar siswa yang belum begitu menunjukkan siswa aktif diskusi. Data hasil observasi aktivitas belajar siswa disajikan dalam Tabel.

Tabel Skor Aktivitas Belajar Siswa

Siklus I

\begin{tabular}{|c|l|c|c|}
\hline No & \multicolumn{1}{|c|}{ Aktivitas } & Skor & Proporsi \\
\hline 1 & $\begin{array}{l}\text { Menulis, } \\
\text { membaca }\end{array}$ & 21.75 & $44 \%$ \\
\hline 2 & $\begin{array}{l}\text { Mengerjakan } \\
\text { LKS }\end{array}$ & 14.5 & $29 \%$ \\
\hline 3 & $\begin{array}{l}\text { Bertanya pada } \\
\text { teman }\end{array}$ & 5 & $10 \%$ \\
\hline 4 & $\begin{array}{l}\text { Bertanya pada } \\
\text { guru }\end{array}$ & 3.75 & $8 \%$ \\
\hline 5 & $\begin{array}{l}\text { Yang tidak } \\
\text { relevan }\end{array}$ & 7.5 & $10 \%$ \\
\hline \multicolumn{2}{|l}{ Jumlah } & 52.5 & $100 \%$ \\
\hline
\end{tabular}

Merujuk pada Tabel aktivitas dominan yang dilakukan siswa adalah menulis dan membaca (44\%) kondisi ini belum sesuai dengan yang diharapkan karena seharusnya aktivitas diskusi lebih dominan ketimbang aktivitas individual tersebut, sementara aktivitasi mengerjakan LKS dalam posisi kedua (29\%), bertanya pada guru (8\%) atau siswa masih sangat bergantung pada guru. Dan aktivitas bertanya pada teman dan yang tidak relevan berturut-turut $(10 \%)$ dan (10\%).

Pada akhir proses belajar mengajar siswa diberi tes Formatif I dengan tujuan untuk mengetahui tingkat keberhasilan siswa dalam proses belajar mengajar yang telah dilakukan. Adapun data hasil formatif pada Siklus I ditunjukkan Tabel. 
Tabel Distribusi Hasil Formatif 1

\begin{tabular}{|c|c|c|}
\hline Nilai & Frekunsi & Rata-rata \\
\cline { 1 - 2 } 40 & 3 & \\
\cline { 1 - 2 } 60 & 7 & \multirow{2}{*}{72.38} \\
\hline 80 & 6 & \\
\hline 100 & 5 & \\
\cline { 1 - 2 } Jumlah & 21 & \\
\hline
\end{tabular}

Merujuk pada Tabel tersebut, nilai terendah Formatif I adalah 40 dan tertinggi adalah 100. Merujuk pada KKM sebesar 65 maka hanya 11 dari 21 orang siswa mendapat nilai ketuntasan atau ketuntasan klasikal tercapai sebesar $52 \%$. Nilai ini berada di bawah kriteria ketuntasan klasikal sebesar $85 \%$ sehingga dapat dikatakan KBM Siklus I gagal memberi ketuntasan belajar dalam kelas. Nilai rata-rata kelas adalah 72.38 masih di bawah KKM. Dengan demikian maka peneliti berusaha melakukan tindakan perbaikan dalam melaksanakan pembelajaran Siklus II yang dirasa perlu.

Penerapan metode pembelajaran Role Playing pada pembelajaran IPS siklus I belum sepenuhnya dapat meningkatkan hasil belajar peserta didik. Hasil belajar pada siklus I ratarata 72,38 nilai terendah 40 dan nilai tertinggi 100. Peserta didik yang tuntas belajar menurut batas KKM 11 orang sedangkan 10 orang lainnya masih belum tuntas dengan ketuntasan klasikal $52 \%$. Hal ini terjadi disebabkan oleh beberapa faktor diantaranya :

1. Metode pembelajaran Role Playing yang diterapkan guru, merupakan bentuk belajar yang baru bagi peserta didik.

2. Dalam pelaksanaan proses pembelajaran masih ada peserta didik yang bermain-main dan bercerita dengan teman, masih sedikit peserta didik yang nampak aktif.

3. Peserta didik belum terbiasa belajar dalam kelompok.

4. Peserta didik malu-malu bertanya.

Berdasarkan refleksi pada pembelajaran pertemuan 1 dan pertemuan 2, dan analisis hasil belajar siklus I maka perlu ada perbaikan pembelajaran berikutnya pada siklus II.

Observasi yang dilakukan dua guru sejawat menghasilkan data aktivitas belajar siswa Siklus II yang mengalami perbaikan dibandingkan Siklus sebelumnya. Data hasil observasi aktivitas belajar siswa disajikan dalam Tabel.

\section{Tabel Skor Aktivitas Belajar Siswa} Siklus II

\begin{tabular}{|c|l|c|c|}
\hline No & \multicolumn{1}{|c|}{ Aktivitas } & Skor & Proporsi \\
\hline 1 & $\begin{array}{l}\text { Menulis, } \\
\text { membaca }\end{array}$ & 15.75 & $30 \%$ \\
\hline 2 & $\begin{array}{l}\text { Mengerjakan } \\
\text { LKS }\end{array}$ & 18.25 & $37 \%$ \\
\hline 3 & $\begin{array}{l}\text { Bertanya pada } \\
\text { teman }\end{array}$ & 10.25 & $18 \%$ \\
\hline 4 & $\begin{array}{l}\text { Bertanya pada } \\
\text { guru }\end{array}$ & 6.25 & $12 \%$ \\
\hline 5 & $\begin{array}{l}\text { Yang tidak } \\
\text { relevan }\end{array}$ & 2 & $3 \%$ \\
\hline \multicolumn{2}{|}{ Jumlah } & 52.5 & $100 \%$ \\
\hline
\end{tabular}

Merujuk pada Tabel aktivitas dominan yang dilakukan siswa adalah mengerjakan LKS (37\%) kondisi ini telah sesuai dengan yang diharapkan karena seharusnya aktivitas kerja memang lebih dominan ketimbang aktivitas individual menulis dan membaca yang berada pada peringkat kedua (30\%), bertanya pada guru turun menjadi $(12 \%)$ atau siswa mulai mandiri. Hal ini diperkuat dengan aktivitas bertanya pada teman dan yang 
tidaka relevan berturut-turut (18\%) dan (3\%).

Pada akhir proses belajar mengajar Siklus II siswa diberi tes Formatif II dengan tujuan untuk mengetahui tingkat keberhasilan siswa dalam proses belajar mengajar yang telah dilakukan. Adapun data hasil formatif pada Siklus II ditunjukkan Tabel.

Tabel Distribusi Hasil Formatif II

\begin{tabular}{|c|c|c|}
\hline Nilai & Frekunsi & Rata-rata \\
\hline 60 & 2 & \multirow{2}{*}{88.57} \\
\cline { 1 - 2 } 80 & 8 & \multirow{2}{*}{8.50} \\
\cline { 1 - 2 } 100 & 11 & \\
\cline { 1 - 2 } Jumlah & 21 & \\
\hline
\end{tabular}

Merujuk pada Tabel tersebut nilai terendah Formatif II adalah 60 dan tertinggi adalah 100. Merujuk pada KKM sebesar 65 maka 19 dari 21 orang siswa mendapat nilai ketuntasan atau ketuntasan klasikal tercapai sebesar $90 \%$. Nilai ini berada di atas kriteria ketuntasan klasikal sebesar $85 \%$ sehingga dapat dikatakan KBM Siklus II berhasil memberi ketuntasan belajar dalam kelas. Nilai rata-rata kelas adalah 88.57 telah mencapai KKM. Dengan demikian maka penelitian telah berhasil memberi ketuntasan klasikal dalam dua siklus.

Penerapan model pembelajaran Role Playing pada pembelajaran IPS siklus II telah dapat meningkatkan hasil belajar peserta didik. Hasil belajar pada siklus II rata-rata 88,57 nilai terendah 60 dan nilai tertinggi 100. Peserta didik yang tuntas belajar menurut batas KKM 19 orang, hanya 2 orang peserta didik yang masih belum tuntas. Namun ketuntasan kelas telah melampaui batas minimal $>85 \%$ yaitu sebesar $85 \%$. Dengan demikian hasil ini dapat dianggap bahwa pembelajaran dengan model pembelajaran Role Playing telah dapat meningkatkan hasil belajar peserta didik dan tidak perlu lagi dilanjutkan pada siklus berikutnya. Keberhasilan pembelajaran pada siklus ini sesuai dengan perbaikan :

1. Peserta didik mulai terbiasa dengan model pembelajaran Role Playing.

2. Dalam pelaksanaan proses pembelajaran peserta didik sudah mulai aktif.

3. Peserta didik mulai terbiasa belajar dalam kelompok.

4. Peserta didik mulai terbiasa bertanya baik pada teman ataupun pada guru.

Setelah dilakukan pembelajaran yang berimplementasi kurikulum Tingkat Satuan Pendidikan dengan metode pembelajaran Role Playing, diperoleh perubahan baik suasana kelas maupun kemampuan peserta didik dalam menyelesaikan LKS dan tes hasil belajar, hal ini dikarenakan dalam setiap proses pembelajaran yang dilakukan dalam penelitian ini mencakup strategistrategi yang terdapat dalam Role Playing, yaitu dapat meningkatkan minat siswa, keaktifan, dan empati siswa. Pada pertemuan pertama antusiasme peserta didik mengikuti proses pembelajaran di awal belum begitu baik, karena peserta didik merasa Role Playing merupakan sesuatu yang baru bagi mereka. Pada siklus I peserta didik tampak masih canggung dan bingung mengikuti alur pembelajaran. Untuk mengatasi kebingungan peserta didik dan memicu partisipasi seluruh peserta didik serta agar peserta didik tidak jenuh sekaligus untuk melihat kemajuan kemampuan peserta didik melengkapi LKS maka komunitas belajar pada siklus II perlu dipersempit lagi. 
Merujuk pada tabel, setelah menganalisis hasil belajar peserta didik pada mata pelajaran IPS dalam menyelesaikan tes akhir siklus, diperoleh rata-rata nilai siswa sebelum penerapkan metode pembelajaran Role Playing adalah 50,59 yang demikian menunjukkan bahwa tidak ada siswa yang tuntas mencapai nilai KKM 65 . nilai rata-rata pada siklus I adalah 72,38. Berdasarkan pekerjaan peserta didik pada siklus I masih ditemukan beberapa penyelesaian yang kurang teliti. Menanggapi hal ini maka guru mengungkapkan kembali kesalahan pengerjaan tersebut pada saat melakukan apersepsi di siklus II.

Pada siklus II rata-rata nilai tes yang diperoleh peserta didik jauh lebih baik dari pada siklus I, yaitu 88,57 dan persentase ketuntasan kelas mencapai $90 \%$, yaitu 19 peserta didik mendapatkan nilai $\geq 65$.

Melihat perkembangan dari pretes, akhir siklus I sampai siklus II pada mata pelajaran IPS terlihat adanya peningkatan rata-rata nilai tes hasil belajar. Walaupun ketuntasan kelas pada siklus I belum tercapai, namun pada siklus II menunjukkan hasil yang diharapkan, rata-rata nilai peserta didik melampaui skor minimal ketuntasan belajar 65 dan ketuntasan kelas mencapai $90 \%$. Sehingga penerapan metode pembelajaran Role Playing dapat meningkatkan hasil belajar siswa pada mata pelajaran IPS di kelas III SD Negeri No. 056612 Pasar Batu T.A. 2015/2016.

Merujuk pada tabel, aktivitas siswa pada siklus I menulis/membaca 44\%, mengerjakan LKS 29\%, bertanya pada teman $10 \%$, bertanya pada guru $8 \%$ dan yang tidak relevan dengan KBM sebesar $10 \%$. Sedangkan pada siklus II menulis/membaca $30 \%$, mengerjakan
LKS $37 \%$, bertanya pada teman $18 \%$, bertanya pada guru $12 \%$ dan yang tidak relevan dengan KBM sebesar 3\%. Sehingga penerapan metode pembelajaran Role Playing dapat meningkatkan aktivitas belajar siswa pada mata pelajaran IPS di kelas III SD Negeri No. 056612 Pasar Batu T.A. 2015/2016.

\section{KESIMPULAN}

1. Hasil belajar peserta didik dengan menerapkan model pembelajaran Role Playing pada mata pelajaran IPS di kelas III SD Negeri No. 056612 Pasar Batu T.A 2015/2016 mengalami peningkatan, pada siklus I nilai rata-rata siswa sebesar 72,38 dengan ketuntasan klasikal $52 \%$ dan pada siklus II nilai ratarata siswa sebesar 88,57 dengan ketuntasan klasikal 90\%.

2. Aktivitas belajar peserta didik dengan menerapkan model pembelajaran Role Playing pada siklus I dan siklus II berdasarkan pengamatan kedua observer adalah: Pengamatan siklus I, menulis/membaca 44\%, mengerjakan LKS 29\%, bertanya pada teman $10 \%$, bertanya pada guru $8 \%$ dan yang tidak relevan dengan KBM sebesar $10 \%$. Sedangkan pada siklus II menulis/membaca $30 \%$, mengerjakan LKS 37\%, bertanya pada teman $18 \%$, bertanya pada guru $12 \%$ dan yang tidak relevan dengan KBM sebesar 3\%.

\section{DAFTAR RUJUKAN}

Aqib, Zainal. 2010. Penelitian Tindakan Kelas. Bandung: Yrama Widya. 
Jurnal Guru Kita (JGK). Vol 1 (2) Maret 2017, hlm. 85-92

Djamarah, Syaiful Bahri dan Aswan Zain. 2002. Strategi Belajar Mengajar. Jakarta: Rineka Cipta.

E. Mulyasa. 2005. Menjadi Guru Profesional. Bandung: PT. Remaja Rosda Karya.

Irmalati. 2016. Meningkatkan Hasil Belajar Siswa Melalui Metode Pembelajaran Role Playing Pada Mata Pelajaran IPS Di Kelas III SD Negeri No. 056612 Pasar Batu T.A 2015/2016. (PTK Karangan Sendiri).

Mukhlis, Abdul. (Ed). 2000. Penelitian Tindakan Kelas. Makalah Panitian Pelatihan Penulisan Karya Ilmiah untuk Guru-guru sekabupaten Tuban.

Prasetyo, Anang. 2001. Metode Role Playing Untuk Meningkatkan Hasil Belajar Siswa Kelas II SLTP N 3 Driyono Gresik. Buletin Pelangi Pendidikan. Edisi IV Tahun II.

Subino. (1987). Konstruksi dan Analisis Tes (Suatu Pengantar Kepada Teori Tes dan Pengukuran). Jakarta: Depdikbud.

Sugiarti, Titik. 1997. Motivasi Belajar. Jakarta: Cerdas Pustaka.

Winkel,W.S. (2004). Bimbingan dan Konseling Di Sekolah Menengah (cetakan VII). Jakarta: Grafindo. 